\title{
Multivariate and geostatistical analyses of the spatial distribution and origin of heavy metals in the agricultural soils in Shunyi, Beijing, China
}

\author{
Anxiang Lu ${ }^{\text {a,b }}$, Jihua Wang ${ }^{\text {b }}$, Xiangyang Qin ${ }^{c}$, Kaiyi Wang ${ }^{c}$, Ping Han ${ }^{\text {b }}$, Shuzhen Zhang a,*

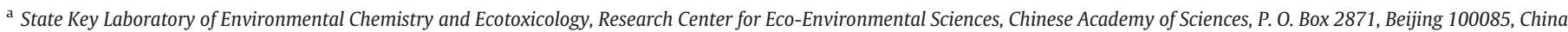 \\ b Beijing Research Center for Agri-food Testing and Farmland Monitoring, Beijing 100097, China \\ c National Engineering Research Center for Information Technology in Agriculture, Beijing 100097, China
}

\section{A R T I C L E I N F O}

\section{Article history:}

Received 19 August 2011

Received in revised form 2 March 2012

Accepted 2 March 2012

Available online 28 March 2012

\section{Keywords:}

Multivariate analysis

Geostatistical analysis

Heavy metal

Agricultural soil

\begin{abstract}
A B S T R A C T
An extensive survey was conducted in this study to determine the spatial distribution and possible sources of heavy metals in the agricultural soils in Shunyi, a representative agricultural suburb in Beijing, China. A total of 412 surface soil samples were collected at a density of one sample per $\mathrm{km}^{2}$, and concentrations of As, Cd, $\mathrm{Cu}, \mathrm{Hg}, \mathrm{Pb}$ and $\mathrm{Zn}$ were analyzed. The mean values of the heavy metals were $7.85 \pm 2.13,0.136 \pm 0.061,22.4 \pm 6.31$, $0.073 \pm 0.049,20.4 \pm 5.2$, and $69.8 \pm 16.5 \mathrm{mg} \mathrm{kg}^{-1}$ for $\mathrm{As}, \mathrm{Cd}, \mathrm{Cu}, \mathrm{Hg}, \mathrm{Pb}$, and $\mathrm{Zn}$, respectively, slightly higher than their background values of Beijing topsoil with the exception of $\mathrm{Pb}$, but lower than the guideline values of Chinese Environmental Quality Standard for Soils. Multivariate and geostatistical analyses suggested that soil contamination of $\mathrm{Cd}, \mathrm{Cu}$ and $\mathrm{Zn}$ was mainly derived from agricultural practices. Whereas, As and $\mathrm{Pb}$ were due mainly to soil parent materials, and $\mathrm{Hg}$ was caused by the atmospheric deposits from Beijing City. The identification of heavy metal sources in agricultural soils is a basis for undertaking appropriate action to protect soil quality.
\end{abstract}

(c) 2012 Elsevier B.V. All rights reserved.

\section{Introduction}

Soil contamination with heavy metals draws great attention because of its potential threat to food safety and detrimental effects on the ecosystem. Heavy metals may come from natural or anthropogenic sources. Natural contents of heavy metals in soils depend primarily on composition of geological parent materials. Human activities such as urban-industrial expansion, fossil fuel combustion and agricultural practices also influence heavy metal contents in soils. Heavy metals in agricultural soils have increased mainly because of the excessive use of fertilizers and pesticides, wastewater irrigation, sewage sludge application and elevated atmospheric deposition (Cai et al., 2009; Chary et al., 2008).

Spatial distribution of heavy metals in agricultural soils is correlated with their natural sources and anthropogenic inputs. Geostatistical methods are useful tools for quantification of the spatial features of soil parameters and performance of spatial interpolation ( $\mathrm{Xu}$ and Tao, 2004; Lee et al., 2006). A combination of multivariate statistics and geostatistical analysis is an advanced method for identifying pollution characteristics of heavy metals in soils and distinguishing their natural sources and anthropogenic inputs. This approach generally consists in performing principal component analysis (PCA) and mapping the scores with geostatistical tools (Rodríguez et al., 2006;

\footnotetext{
* Corresponding author. Tel.: + 86 1062849683; fax: + 861062923563. E-mail address: szzhang@rcees.ac.cn (S. Zhang).
}

López et al., 2008; Lado et al., 2008). Furthermore, spatially constrained multivariate analysis methods (MULTISPATI-PCA) were developed to consider the relationship among variables and their spatial structure together (Dray et al., 2008; Saby et al., 2009). Multivariate and geostatistical analyses have also been applied in the studies of spatial uncertainty and hazard assessment (Liu et al., 2006; Hang et al., 2009; Chen et al., 2009).

Beijing, the capital of China, is one of the largest cities in the world. Over the last decades, soil contamination problems in Beijing have emerged gradually as the rapid economic growth (Khan et al., 2008; Luo et al., 2008). There have been concerns about the quality of the agricultural soils around the megalopolis, considering the potential negative environmental influences from the city. Another threat to the agricultural soils is possibly the intensive agricultural practice such as excessive use of chemical fertilizers and pesticides encouraged by economic interest. A few researches have been conducted so far to determine the concentration and spatial distribution of heavy metals in the soils around cities (Saby et al., 2006; Ip et al., 2007; Shi et al., 2008; Hang et al., 2009). However, studies on the characteristics and sources of heavy metals in agricultural soils nearby big cities are still in need (Liu et al., 2006; Chen et al., 2009).

Therefore, an intensive survey was conducted in the present study to profile the heavy metal concentrations in the agricultural soils in the Shunyi District, selected as a representative agricultural area in the Beijing suburb. A total of 412 soil samples were collected and analyzed for $\mathrm{As}, \mathrm{Cd}, \mathrm{Cu}, \mathrm{Hg}, \mathrm{Pb}$ and $\mathrm{Zn}$. Multivariate and geostatistical analyses were combined to investigate the current state of soil heavy metal contamination in this area and to identify the spatial 


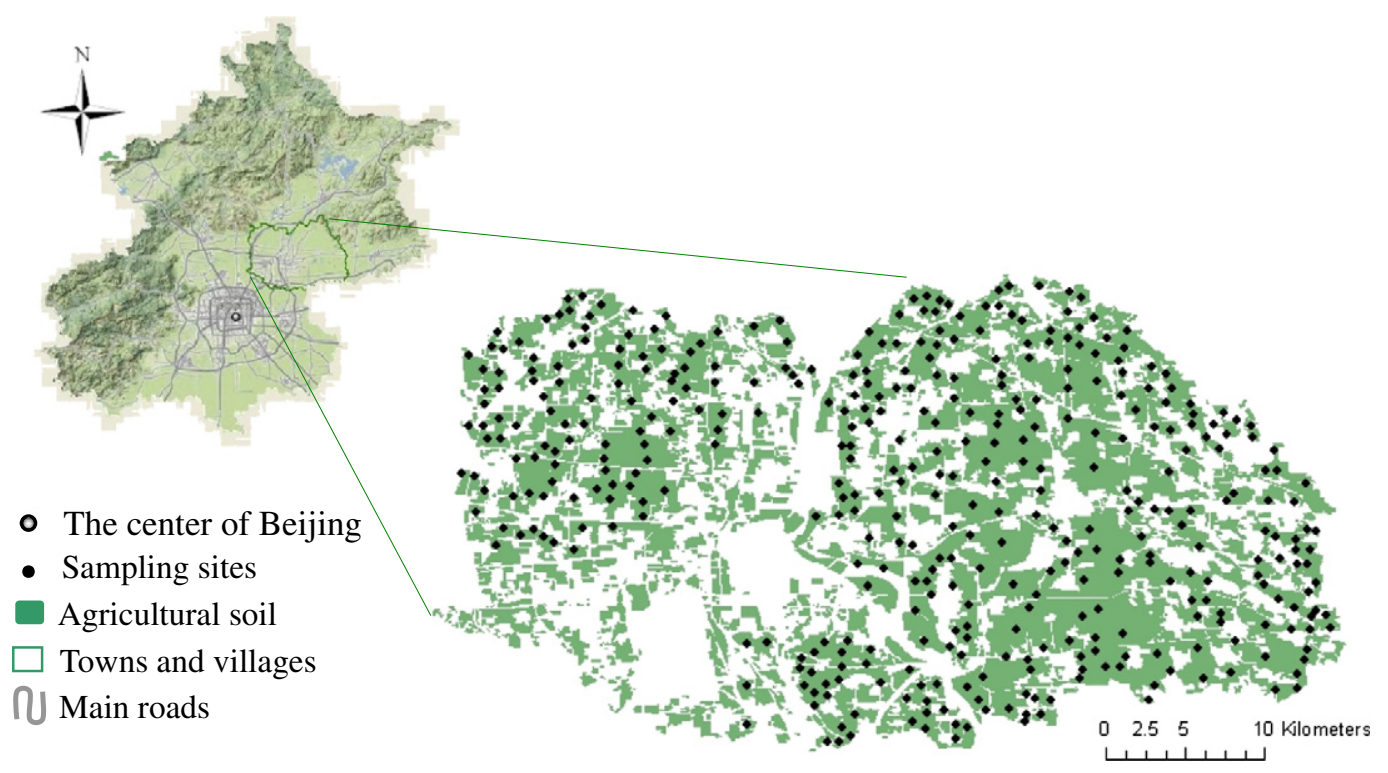

Fig. 1. Location of the sampling sites.

patterns and the possible sources of the heavy metals. Such research will provide a basis for effectively targeting policies to protect soils from long-term accumulation of heavy metals.

\section{Material and methods}

\subsection{Study area}

The Shunyi District is located in the northeast of Beijing and covers about $1021 \mathrm{~km}^{2}$. This district has been traditionally associated with agricultural activities, and the approximately $5.0 \times 10^{5}$ ha of the agricultural lands mainly consist of croplands, vegetable farms, fruit farms and grasslands. Shunyi has a typical monsoon-influenced climate, characterized by hot and humid summer and generally cold and dry winter. The annual temperature is approximately $11.5^{\circ} \mathrm{C}$, and the annual precipitation is approximately $600 \mathrm{~mm}$.

\subsection{Soil sampling and chemical analysis}

A total of 412 topsoil samples $(0-20 \mathrm{~cm}$ depth) were collected from the agricultural areas in Shunyi District in the period of August to November, 2009 (Fig. 1). The sampling design was based on the distribution of local agricultural land use. Sampling sites were randomly chosen with the density of about one every $1 \mathrm{~km}^{2}$ and at least $200 \mathrm{~m}$ away from industry, traffic and residential areas. Around

Table 1

Descriptive statistics of heavy metal concentrations in the agricultural soils of the Shunyi District.

\begin{tabular}{cccclllll}
\hline & \multicolumn{2}{l}{ Concentration $\left(\mathrm{mg} \mathrm{kg}^{-1}\right)$} & \multirow{2}{l}{$\begin{array}{l}\text { Std. } \\
\text { deviation }\end{array}$} & $\begin{array}{l}\text { C.V. } \\
(\%)\end{array}$ & Skewness & Kurtosis & K-S \\
\cline { 2 - 5 } & Mean & Min & Max & & & & & \\
\hline As & 7.85 & 3.37 & 17.3 & 2.13 & 27.1 & 1.11 & 2.31 & $1.28^{*}$ \\
$\mathrm{Cd}$ & 0.136 & 0.015 & 0.469 & 0.061 & 44.9 & 2.00 & 6.36 & 3.00 \\
$\mathrm{Cu}$ & 22.4 & 11.8 & 72.5 & 6.31 & 28.2 & 2.47 & 12.3 & 2.80 \\
$\mathrm{Hg}$ & 0.073 & 0.004 & 0.490 & 0.049 & 67.1 & 3.03 & 19.1 & 2.19 \\
$\mathrm{~Pb}$ & 20.4 & 10.3 & 37.5 & 5.20 & 25.5 & 0.180 & -0.480 & $1.12^{*}$ \\
$\mathrm{Zn}$ & 69.8 & 20.0 & 137 & 16.5 & 23.6 & 0.640 & 2.31 & 1.76 \\
\hline
\end{tabular}

* Asymptotic significance $>0.05$ (2-tailed). the center of each site, five individual sub-samples were collected from a $10 \mathrm{~m} \times 10 \mathrm{~m}$ grid using a wood spade. Sub-samples were bulked to obtain a composite sample for each site. Coordinates of the sampling points were recorded using global positioning system. Information on vegetation and soil type was also recorded. According to the USDA Soil Taxonomy, the soils belong to Ustalfs and Ustochrepts.

Approximately $1.0 \mathrm{~kg}$ of each soil sample was taken and mixed thoroughly. The soil samples were air-dried and passed through a $2.0 \mathrm{~mm}$-sieve. Portions (approximately $50 \mathrm{~g}$ ) of the soil samples were ground in an agate grinder, sieved through a $0.15 \mathrm{~mm}$-sieve, and stored in brown bottles at $4{ }^{\circ} \mathrm{C}$ for chemical analysis.

The soil samples were digested in triplicate with the mixture of $\mathrm{HNO}_{3}, \mathrm{HCl}$ and $\mathrm{H}_{2} \mathrm{O}_{2}$ using Method 3050B (USEPA, 1996). Concentrations of $\mathrm{Cd}, \mathrm{Cu}, \mathrm{Pb}$ and $\mathrm{Zn}$ in the digestion solution were determined by inductively coupled plasma optical emission spectroscopy (Thermo iCAP 6300, USA). Concentrations of As and $\mathrm{Hg}$ in the soils were determined by atomic fluorescence spectrometry (Titan AFS 830, China) after digestion of the soil samples with

Table 2

Average heavy metal concentrations in the soils from different areas.

\begin{tabular}{|c|c|c|c|c|c|c|c|}
\hline \multirow[t]{2}{*}{ Location } & \multicolumn{6}{|c|}{ Concentration $\left(\mathrm{mg} \mathrm{kg}^{-1}\right)$} & \multirow[t]{2}{*}{ Reference } \\
\hline & As & $\mathrm{Cd}$ & $\mathrm{Cu}$ & $\mathrm{Hg}$ & $\mathrm{Pb}$ & $\mathrm{Zn}$ & \\
\hline Beijing (background) & 7.09 & 0.119 & 18.7 & - & 24.6 & 59.6 & $\begin{array}{l}\text { Chen et al. } \\
\text { (2004) }\end{array}$ \\
\hline Beijing (topsoil) & 8.35 & 0.148 & 23.7 & - & 28.6 & 65.6 & $\begin{array}{l}\text { Zheng et } \\
\text { al. (2008) }\end{array}$ \\
\hline $\begin{array}{l}\text { Beijing } \\
\text { (wastewater-irrigated) }\end{array}$ & - & 0.84 & 32.8 & - & 49.4 & 157 & $\begin{array}{l}\text { Khan et al. } \\
\text { (2008) }\end{array}$ \\
\hline $\begin{array}{l}\text { Beijing } \\
\text { (Guanting reservoir) }\end{array}$ & 7.84 & 0.81 & 61.5 & - & 161 & 86.3 & $\begin{array}{l}\text { Luo et al. } \\
\text { (2007) }\end{array}$ \\
\hline $\begin{array}{l}\text { Nanjing } \\
\text { (agricultural soil) }\end{array}$ & 9.59 & 0.17 & 31.2 & 0.12 & 30.3 & 78.9 & $\begin{array}{l}\text { Liao et al. } \\
\text { (2007) }\end{array}$ \\
\hline Hanzhou (rural soil) & 6.25 & 0.26 & 36.6 & 0.69 & 46.2 & 116 & $\begin{array}{l}\text { Chen et al. } \\
\text { (2008) }\end{array}$ \\
\hline $\begin{array}{l}\text { Hong Kong } \\
\quad \text { (suburban soil) }\end{array}$ & - & 0.37 & 9.72 & - & 57.8 & 67.9 & $\begin{array}{l}\text { Lee et al. } \\
\text { (2006) }\end{array}$ \\
\hline Shunyi (agricultural soil) & 7.85 & 0.136 & 22.4 & 0.073 & 20.4 & 69.8 & $\begin{array}{l}\text { Present } \\
\text { study }\end{array}$ \\
\hline
\end{tabular}


Table 3

Results of ANOVA and Kruskal-Wallis test for the soil samples among different defined group.

\begin{tabular}{|c|c|c|c|c|}
\hline & \multicolumn{2}{|c|}{ Land uses $(\mathrm{df}=3)$} & \multicolumn{2}{|c|}{ Soil types $(\mathrm{df}=1)$} \\
\hline & $\mathrm{F}$ & Sig. & $\mathrm{F}$ & Sig. \\
\hline As & 1.998 & 0.114 & 19.79 & $0.001^{*}$ \\
\hline $\mathrm{Cd}^{\mathrm{a}}$ & 7.377 & 0.061 & 0.870 & 0.351 \\
\hline $\mathrm{Cu}^{\mathrm{a}}$ & 17.56 & $0.001^{*}$ & 3.624 & 0.057 \\
\hline $\mathrm{Hg}^{\mathrm{a}}$ & 7.445 & 0.059 & 3.603 & 0.058 \\
\hline $\mathrm{Pb}$ & 0.276 & 0.843 & 3.642 & 0.057 \\
\hline $\mathrm{Zn}^{\mathrm{a}}$ & 15.06 & $0.002^{*}$ & 0.532 & 0.466 \\
\hline
\end{tabular}

a Chi-square of Kruskal-Wallis test.

* Significance level of 0.05 .

$\mathrm{HNO}_{3}: \mathrm{HCl}(10 \mathrm{ml}, 1: 1 \mathrm{v} / \mathrm{v})$ at $100{ }^{\circ} \mathrm{C}$ for $2 \mathrm{~h}$ and hydride generation with $\mathrm{NaBH}_{4}$ in $\mathrm{HCl}$ medium (Lacerda et al., 2004). All the chemicals used were of guaranteed reagent grade. Standard reference materials, GSS-1 and GSS-4 obtained from the Center of National Standard Reference Material of China, were analyzed as part of quality assurance and quality control (QA/QC) procedures. Good agreement was achieved between the data obtained from the present work and the certified values with the recoveries between 93 and $109 \%$. Analysis of the samples including soil digests and blanks was set up in triplicate, and the standard deviation was within $5 \%$.

\subsection{Data statistical analysis}

Statistical analysis was conducted using SPSS 16.0 (SPSS Inc., USA). Analysis of variance (ANOVA) was used to compare data from the different groups of soil samples (i.e., different land uses and soil types). If the data is non-normally distributed, non-parametric test (Kruskal-Wallis test) was applied. Principal component analysis (PCA) was carried out to cluster metals that behaved similarly to identify potential sources.

\subsection{Geostatistical analysis}

The main application of geostatistics to soil science has been the estimation, prediction and mapping of soil attributes in un-sampled areas. The semivariogram, $\gamma(\mathbf{h})$, measures the mean variability between two points $x$ and $x+h$, as a function of their distance $\mathbf{h}$.

The experimental semivariances were calculated with Matheron's classical estimator (Matheron, 1965) by the following equation:

$\gamma(\mathbf{h})=\frac{1}{2 N(\mathbf{h})} \sum_{i=1}^{n}\left[Z\left(\mathbf{x}_{i}\right)-Z\left(\mathbf{x}_{i}+\mathbf{h}\right)\right]^{2}$

where $Z\left(\mathbf{x}_{i}\right)$ is the value of $Z$ at location $\mathbf{x}_{i}$, and $Z\left(\mathbf{x}_{i}+\mathbf{h}\right)$ is the value of $Z$ at a location separated from $\mathbf{x}_{i}$ by distance $\mathbf{h}$. $N$ is the number of pairs of points which are $\mathbf{h}$ distance apart.
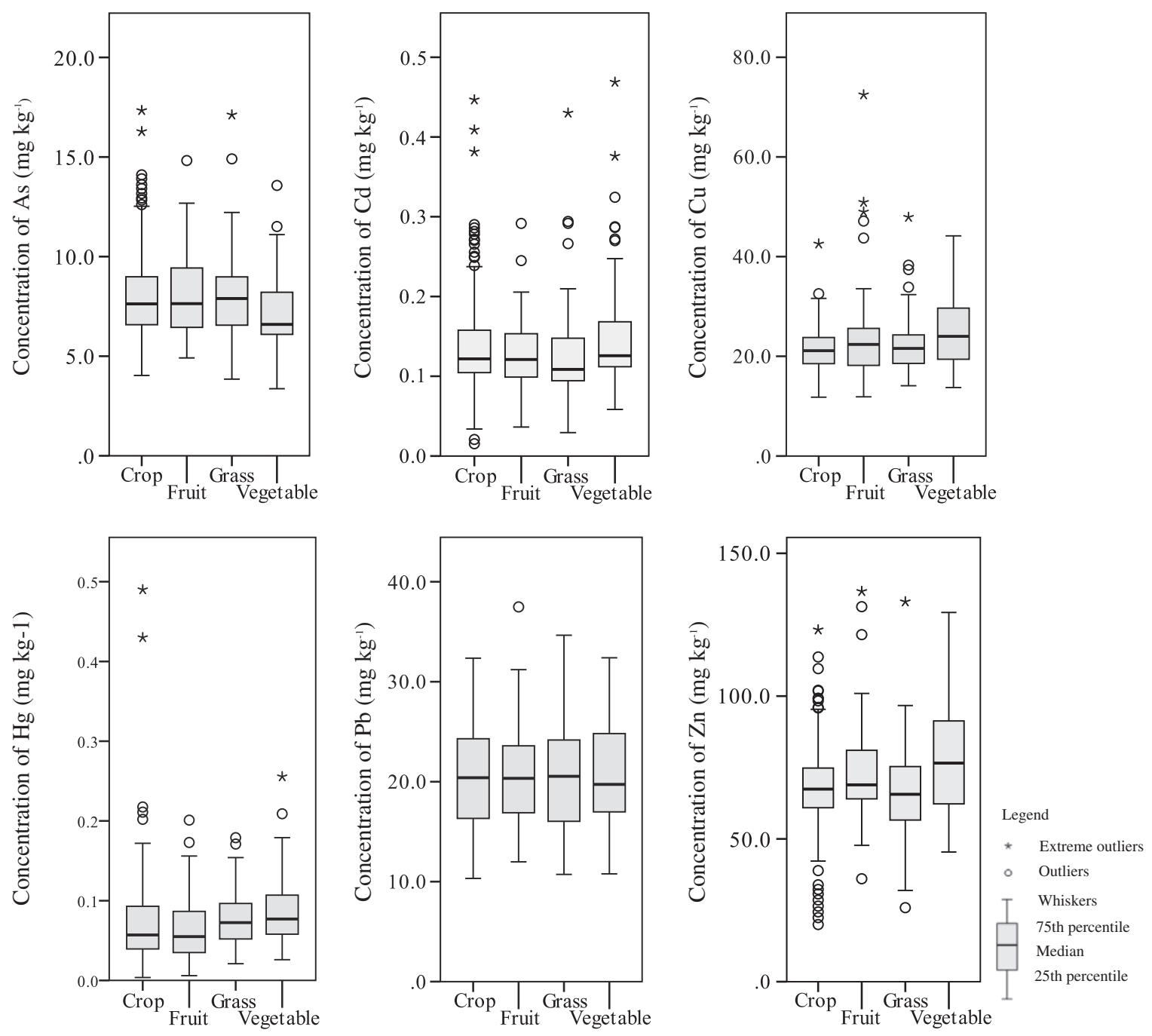

Fig. 2. Box-and-whisker plots for $\mathrm{As}, \mathrm{Cd}, \mathrm{Cu}, \mathrm{Hg}, \mathrm{Pb}$ and $\mathrm{Zn}$ in the agricultural soils under different patterns of land use. 

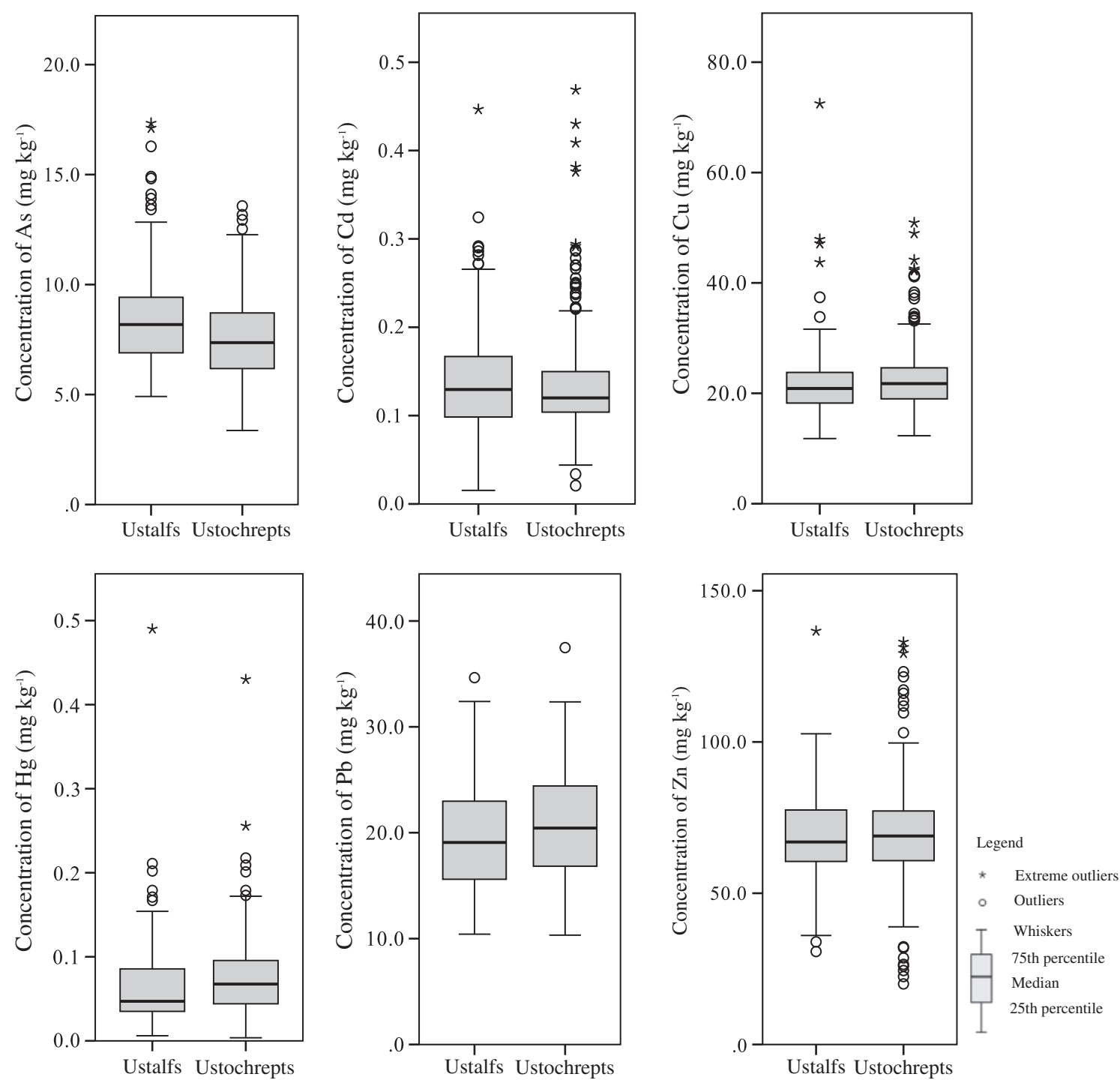

Fig. 3. Box-and-whisker plots for $\mathrm{As}, \mathrm{Cd}, \mathrm{Cu}, \mathrm{Hg}, \mathrm{Pb}$ and $\mathrm{Zn}$ in the soils of Ustalfs and Ustochrepts.

Table 4

Total variance explained and component matrix for heavy metals in the soils.

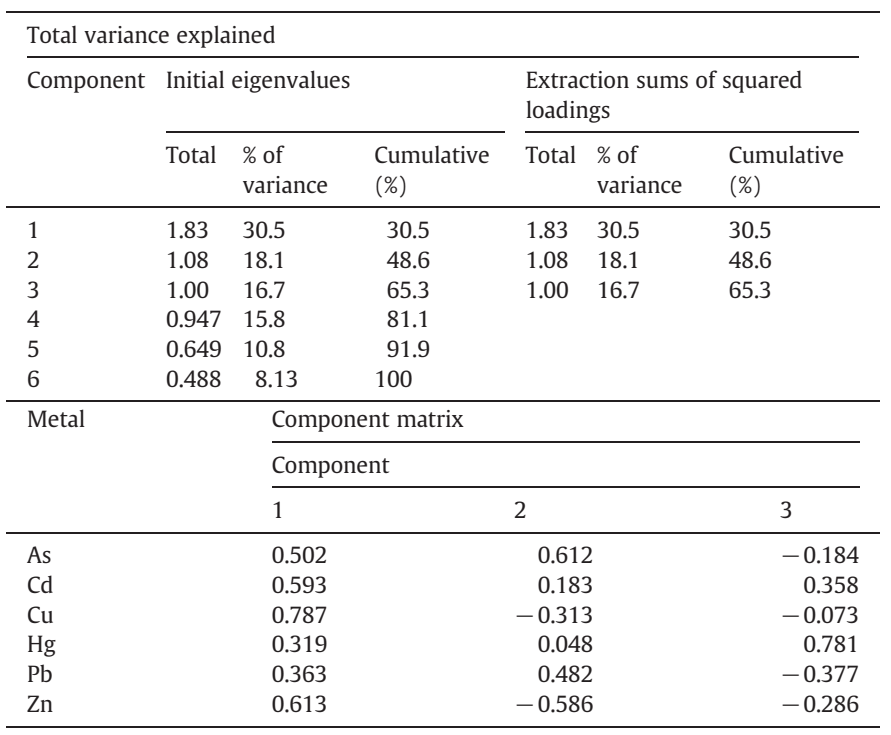

Extraction method: principal component analysis.
In the case that concentrations of heavy metals in soil samples display a skewed distribution, the outliers have a large effect on estimates of the variogram calculated (Lark, 2002). Robust estimators may be used to obtain the experimental variogram with minimum effect of the outliers and then robust kriging are used for estimation (Cressie and Hawkins, 1980):

$\gamma(\mathbf{h})=\frac{1}{2}\left\{\frac{1}{N(\mathbf{h})} \sum_{i=1}^{n}\left[Z\left(\mathbf{x}_{i}\right)-Z\left(\mathbf{x}_{i}+\mathbf{h}\right)\right]^{1 / 2}\right\}^{4} \times \frac{1}{0.457+\frac{0.494}{N(\mathbf{h})}}$

where $Z\left(\mathbf{x}_{i}\right)$ is the value of $Z$ at location $\mathbf{x}_{i}$, and $Z\left(\mathbf{x}_{i}+\mathbf{h}\right)$ is the value of $Z$ at a location separated from $\mathbf{x}_{i}$ by distance $\mathbf{h}$. $N$ is the number of pairs of points which are $\mathbf{h}$ distance apart.

The experimental variogram is calculated for several lag distances. It is then fitted with theoretical models such as spherical, exponential and linear models. These models provide information about the structure of the spatial variation and the input parameters for spatial prediction by kriging interpolation (Goovaerts, 1999). Selection of the best-fit variogram model was made on the basis of cross-validation. The procedure of leave-one-out cross-validation is to delete one data and use the remaining data to predict the 
deleted observation. Lark (2000) proposed to calculate the statistic $\theta\left(\mathbf{x}_{i}\right)$

$\theta\left(\mathbf{x}_{i}\right)=\frac{\left\{Z\left(\mathbf{x}_{i}\right)-\bar{Z}\left(\mathbf{x}_{i}\right)\right\}^{2}}{\sigma^{2}\left(\mathbf{x}_{i}\right)}$

where $Z\left(\mathbf{x}_{i}\right)$ is the observed value at location $\mathbf{x}_{i}, \widehat{Z}\left(\mathbf{x}_{i}\right)$, is the kriging estimated value and $\sigma^{2}\left(\mathbf{x}_{i}\right)$ is the kriging variance.

If the fitted variogram is a valid representation of the spatial variation, $\sigma\left(\mathbf{x}_{i}\right)$ should be distributed as $\chi^{2}$ with one degree of freedom with $E\left[\theta\left(\mathbf{x}_{i}\right)\right]=1$.0. Lark (2000) has demonstrated that it is preferable to use the median of $\theta(\mathbf{x})$ instead of the mean value to assess the variogram. The median value of $\theta(\mathbf{x})$ enables comparison of results of cross validation for kriging with different variogram models, the criterion for the decision is to select the model with the median value of $\theta(\mathbf{x})$ closest to 0.455 .

The experimental variogram model was obtained using GeoR 1.7-1 package (Ribiero and Diggle, 2001) under R 2.14 software ( $R$ Development Core Team, 2011). Kriging interpolation and mapping were conducted using ArcGis 9.0 (ESRI Inc., USA).

\section{Results and discussion}

\subsection{Heavy metal concentrations in the soils}

The descriptive statistics of the heavy metal concentrations in the agricultural soils are presented in Table 1 . The mean values were $7.85 \pm 2.13,0.136 \pm 0.061,22.4 \pm 6.31,0.073 \pm 0.049,20.4 \pm 5.2$, and $69.8 \pm 16.5 \mathrm{mg} \mathrm{kg}^{-1}$ for As, Cd, Cu, Hg, Pb and Zn, respectively. Application of the $\mathrm{K}-\mathrm{S}$ test confirmed that the concentrations of $\mathrm{Cd}, \mathrm{Cu}, \mathrm{Hg}$ and $\mathrm{Zn}$ in the soils were non-normally distributed; whereas $\mathrm{As}$ and $\mathrm{Pb}$ concentrations were normally distributed. After log-transformation, the distributions of $\mathrm{Cd}, \mathrm{Cu}, \mathrm{Hg}$ and $\mathrm{Zn}$ were still non-normal. For comparison purpose, data gathered from the recent investigations on heavy metal concentrations in the soils in Beijing and in several other cities of China are summarized in Table 2. Heavy metal concentrations in Shunyi were slightly higher than the background values of Beijing topsoils with the exception of $\mathrm{Pb}$, suggesting a slight contamination of heavy metals in this area. Lower $\mathrm{Pb}$ concentration can be adequately explained by the fact that the sampling sites were located in an agricultural region where $\mathrm{Pb}$ contamination from traffic and industry was less serious than the other areas in the city. The concentrations of these metals were also generally lower than those in the other areas in Beijing and several other cities in China. According to the Chinese Environmental Quality Standard for Soils (State Environmental Protection Administration of China, 1995), the guideline values of heavy metal concentrations in soil for agricultural products and human heath are 20,0.6, 100,1.0, 350 and $300 \mathrm{mg} \mathrm{kg}^{-1}$ for As, $\mathrm{Cd}, \mathrm{Cu}, \mathrm{Hg}, \mathrm{Pb}$ and $\mathrm{Zn}$, respectively. Obviously, heavy metal concentrations in these 412 soil samples collected in Shunyi are all below the guideline values.

\subsection{Comparison of heavy metal concentrations in the soils among different agricultural land uses and between soil types}

Land use and soil type are supposed to influence heavy metal accumulation in agricultural soils. Prior to analyzing their influences on soil metal concentrations, an assumption was made that heavy metal concentrations in the soils differ among the defined groups of agricultural land uses (i.e., crop, fruit, grass and vegetable) and between the two soil types (i.e., Ustalfs and Ustochrepts). ANOVA was applied to the data set to determine whether the mean values of the concentrations of $\mathrm{As}$ and $\mathrm{Pb}$ differ among the defined groups, and Kruskal-Wallis test was used for the non-normal distributed metals $(\mathrm{Cu}, \mathrm{Cd}, \mathrm{Hg}$ and $\mathrm{Zn})$. The results are listed in Table 3. Significant
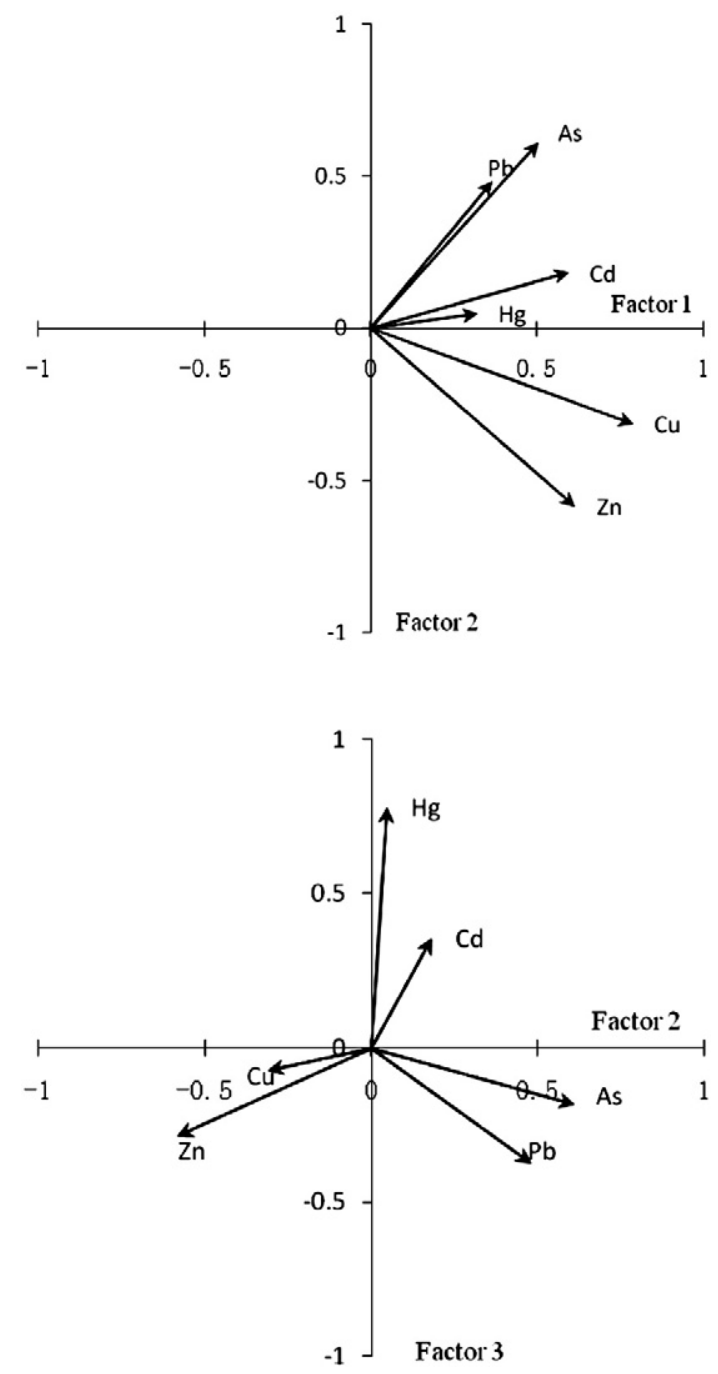

Fig. 4. Graphical display of the first three factors of the PCA.

differences were found in $\mathrm{Cu}$ and $\mathrm{Zn}$ concentrations among different agricultural land uses and As concentration between the two soil types. Figs. 2 and 3 present the box-and-whisker plots of the results. The concentrations of $\mathrm{Cu}$ and $\mathrm{Zn}$ were higher in the vegetable farm soils than in the other soils (Fig. 2), reflecting heavy metal contamination derived from agricultural practices. Generally, vegetable farms are more intensively managed than the others based on agronomic practices such as excessive fertilization and pesticide application. Higher As concentration in the Ustalfs than in the Ustochrepts (Fig. 3) should attribute to the higher As content in the soil parent materials of Ustalfs (Chen et al., 2002).

\subsection{PCA for heavy metals in the soils}

PCA was used to identify the origin of the heavy metals in the agricultural soils, and the results are presented in Table 4. The eigenvalues of the third extracted components were all greater than 1.0. Therefore, the heavy metals could be grouped into a three-component model that accounts for $65 \%$ of all the data variation. The component matrix showed that $\mathrm{Cd}, \mathrm{Cu}$ and $\mathrm{Zn}$ were strongly associated with the first component (factor 1). The second component (factor 2) included As and $\mathrm{Pb}$. Hg was the only element in the third component (factor 3). Fig. 4 shows a graphical display of the first three factors. Base on the above comparison of heavy metal concentrations in the soils among different agricultural 

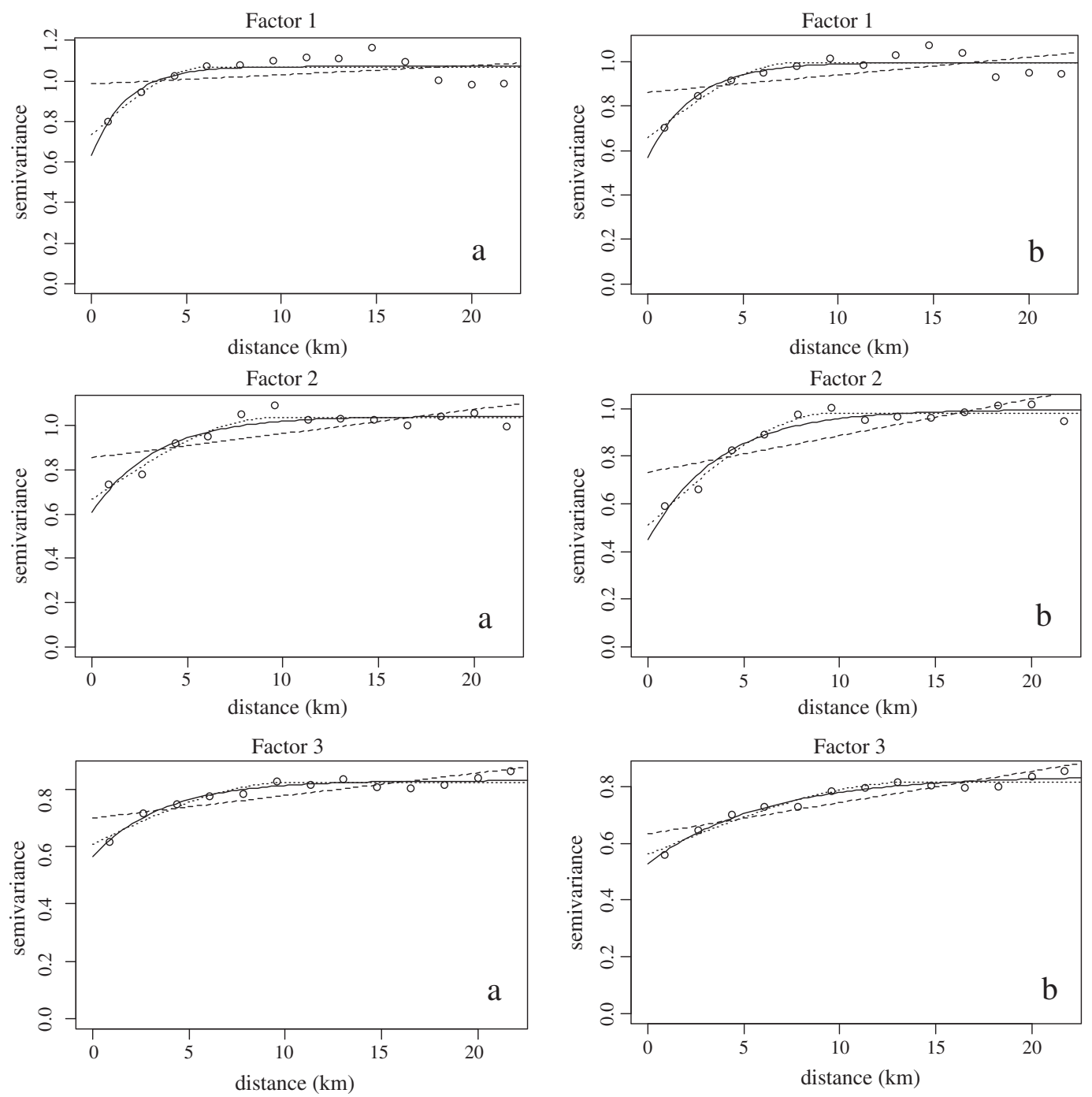

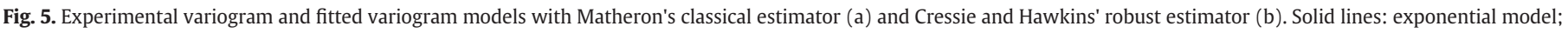
dash line: spherical model; dot line: linear model.

land uses and between soil types and as well as the grouping of the metals suggested with PCA results (Table 4), Cd, Cu and $\mathrm{Zn}$ (factor 1) were controlled by the anthropogenic input from agricultural production, whereas As and $\mathrm{Pb}$ (factor 2) appeared to be associated with soil parent materials. Atmospheric deposition is as a possible source of $\mathrm{Hg}$ (factor 3 ) in the soils (Jin et al., 2008).

Table 5

The parameters and the cross-validation results of the fitted variogram models with different estimators for the three factors.

\begin{tabular}{|c|c|c|c|c|c|c|c|c|c|}
\hline & Estimator & Model & $\mathrm{C}_{0}$ & $\mathrm{C}+\mathrm{C}_{0}$ & $\mathrm{C}_{0} / \mathrm{C}+\mathrm{C}_{0}$ & Range (km) & $\mathrm{RSS}^{\mathrm{a}}$ & Mean of $\theta(\mathbf{x})$ & Median of $\theta(\mathbf{x})$ \\
\hline \multirow[t]{6}{*}{ Factor 1} & \multirow[t]{3}{*}{ Matheron } & Exponential $^{*}$ & 0.632 & 1.07 & 0.591 & 1.87 & 0.0339 & 1.02 & $0.452^{*}$ \\
\hline & & Spherical & 0.732 & 1.07 & 0.684 & 6.09 & 0.0348 & 1.07 & 0.481 \\
\hline & & Linear & 0.985 & 0.999 & 0.986 & 22.6 & 0.0970 & 1.02 & 0.404 \\
\hline & \multirow{3}{*}{ Cressie-Hawkins } & Exponential & 0.571 & 0.996 & 0.573 & 2.46 & 0.0194 & 1.33 & 0.573 \\
\hline & & Spherical & 0.655 & 0.989 & 0.662 & 7.55 & 0.0202 & 1.38 & 0.606 \\
\hline & & Linear & 0.861 & 0.869 & 0.991 & 22.6 & 0.0761 & 1.32 & 0.525 \\
\hline \multirow[t]{6}{*}{ Factor 2} & \multirow[t]{3}{*}{ Matheron } & Exponential & 0.608 & 1.04 & 0.585 & 3.35 & 0.0176 & 1.12 & 0.358 \\
\hline & & Spherical $^{*}$ & 0.667 & 1.04 & 0.641 & 9.47 & 0.0104 & 1.14 & $0.476^{*}$ \\
\hline & & Linear & 0.856 & 0.867 & 0.987 & 22.6 & 0.0733 & 1.32 & 0.382 \\
\hline & \multirow{3}{*}{ Cressie-Hawkins } & Exponential & 0.448 & 0.995 & 0.450 & 3.72 & 0.0137 & 1.68 & 0.518 \\
\hline & & Spherical & 0.509 & 0.981 & 0.519 & 9.55 & 0.00779 & 1.72 & 0.522 \\
\hline & & Linear & 0.732 & 0.747 & 0.980 & 22.6 & 0.0892 & 1.78 & 0.604 \\
\hline \multirow[t]{6}{*}{ Factor 3} & \multirow[t]{3}{*}{ Matheron } & Exponential & 0.567 & 0.831 & 0.682 & 3.63 & 0.00333 & 1.46 & 0.540 \\
\hline & & Spherical $^{*}$ & 0.610 & 0.825 & 0.739 & 10.2 & 0.00462 & 1.44 & $0.538^{*}$ \\
\hline & & Linear & 0.700 & 0.708 & 0.989 & 22.6 & 0.0164 & 1.57 & 0.581 \\
\hline & \multirow[t]{3}{*}{ Cressie-Hawkins } & Exponential & 0.528 & 0.836 & 0.632 & 5.95 & 0.00308 & 1.75 & 0.653 \\
\hline & & Spherical & 0.561 & 0.816 & 0.688 & 14.0 & 0.00506 & 1.74 & 0.638 \\
\hline & & Linear & 0.638 & 0.649 & 0.983 & 22.6 & 0.0151 & 1.91 & 0.705 \\
\hline
\end{tabular}

a Residual sum of squares.

* The closest to 0.455 . 


\subsection{Multivariate geostatistical analysis and spatial distribution map}

A variogram analysis was conducted to further substantiate the above results of the PCA. Fig. 5 shows the experimental variograms and fitted variogram models with Matheron's classical estimator and Cressie and Hawkins' robust estimator for the scores of the first three factors. The parameters and cross-validation results for these models are presented in Table 5 . The model with the median value of $\theta(\mathbf{x})$ closest to 0.455 was selected as inputs for kriging maps. The median values of $\theta(\mathbf{x})$ of selected model were all within the $95 \%$ confidence limits. This indicates that the Matheron's classical estimator can adequately model the spatial variation.

The filled contour maps are shown in Figs. 6 to 8. The ranges of the three factors were classified into five quantiles taking the lowest and the highest values into consideration. As shown in Fig. 6a, the spatial distribution of factor 1 demonstrated several localized hotspots. The hotspot with the highest value of factor 1 ( $\mathrm{Cd}, \mathrm{Cu}$ and $\mathrm{Zn}$ ) was distributed in the south of Shunyi, which coincided with the evidence of vegetable farming in this area in Fig. $6 \mathrm{~b}$ (see the cycles to highlight), suggesting that vegetable farming may contribute to the contamination of $\mathrm{Cd}, \mathrm{Cu}$ and $\mathrm{Zn}$. Chemical fertilizers and manures are intensively used to increase agricultural products. In particular, phosphate fertilizers contain high levels of $\mathrm{Cd}$ due to its presence in phosphate rocks (Luo et al., 2007; Nan et al., 2002). Cu and Zn are present in almost all agricultural inputs, especially in animal manure because of their use as feed additives to promote animal growth and to control diseases (McBride and Spiers, 2001). Liu et al. (2006) contributed the high
$\mathrm{Cu}$ concentration in soils to the extensive manure application in paddy fields. Livestock manures are also important sources of soil $\mathrm{Zn}$ and $\mathrm{Cu}$ pollution. These sources were found to be responsible for an estimated $37 \%$ of $\mathrm{Zn}$ and $8 \%$ of $\mathrm{Cu}$ inputs in the agricultural soils in England and Wales (Nicholson et al., 2003). The application of $\mathrm{Cu}$ containing pesticides or fungicides such as Bordeaux mixture in agriculture especially in vegetable and fruit production may also be a source of $\mathrm{Cu}$ contamination.

The kriging contour map of factor 2 (Fig. 7a) illustrates the distribution of As and $\mathrm{Pb}$. It is difficult to find any link between the factor distribution and the agricultural land use (Fig. 6b). In comparison we can find several consistent locations of high values of factor 2 and the sites of soils predominantly Ustalfs (Fig. 7b), and factor 2 is therefore likely due to the local variation in parent material. As shown in Fig. 3, there was a significant difference in As concentration between the Ustalfs and the Ustochrepts. Elements of As and $\mathrm{Pb}$ may be derived from the soil parent matrix. The background concentration of As in Florida surface soils was evidenced to vary greatly among soil types (Chen et al., 2002). Navas and Machín (2002) also found that soil type determined to some extent the variation of As concentration in the soils of Aragón Spain. The natural level of $\mathrm{Pb}$ concentration in the studied region was contributed by the sampling sits away from industry and traffic pollution.

Contaminants released from the central city may migrate to the surrounding suburb areas. Nevertheless, no evidence was found that factors 1 and 2 decreased along with the distance from the center of the city (Figs. 6a and 7a), suggesting insignificant transport of As,

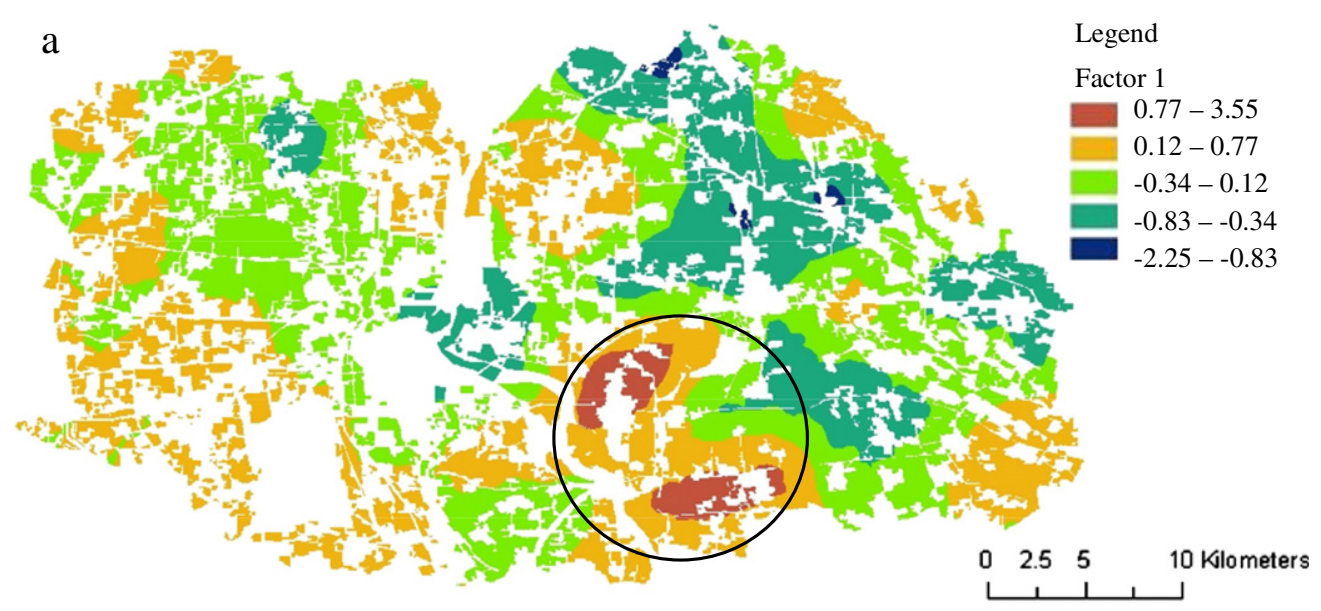

$\mathrm{b}$
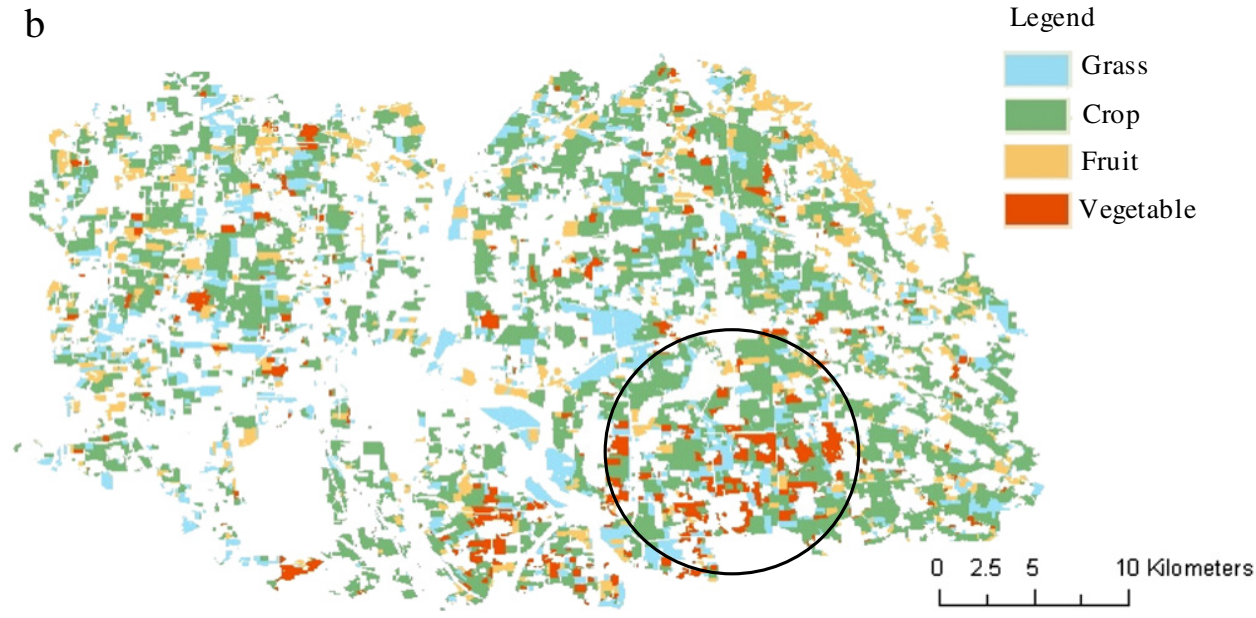

Fig. 6. Filled contour map of factor 1 (a) and agricultural land use map (b). 

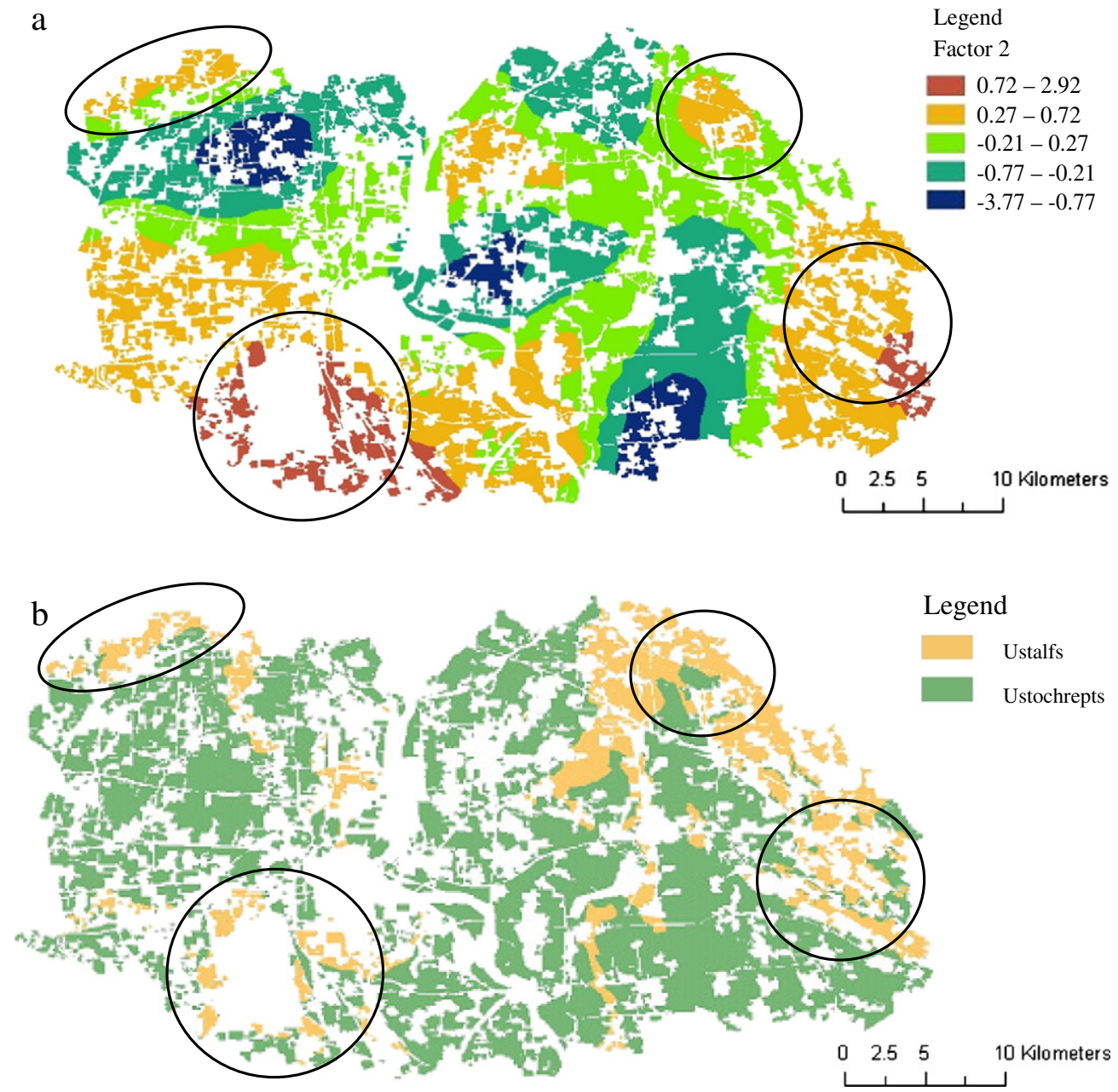

Fig. 7. Filled contour map of factor 2 (a) and soil type map (b).

$\mathrm{Cu}, \mathrm{Cd}, \mathrm{Pb}$ and $\mathrm{Zn}$ from the city to the rural areas. However, the highest value of factor 3 was observed in the south part (cycled in Fig. 8), the closest to the central city. Biasioli et al. (2006) compared a set of soils collected from the city of Torino and its surrounding rural areas. They reported that the transport of heavy metals $(\mathrm{Cu}, \mathrm{Cr}, \mathrm{Pb}$ and $\mathrm{Zn})$ from the city to the surrounding areas was limited to approximately a 1-km circumferential strip. $\mathrm{Hg}$ can accumulate in soils through atmospheric deposition and shows distinguished spatial distribution, because airborne pollutants are supposed to be deposited to soil in a declining trend with distance away from the source. A survey showed that $\mathrm{Hg}$ concentrations in the soils of Beijing were 1.0, 0.30 and $0.18 \mathrm{mg} \mathrm{kg}^{-1}$ in the area inside 2 nd ring road (in the inner

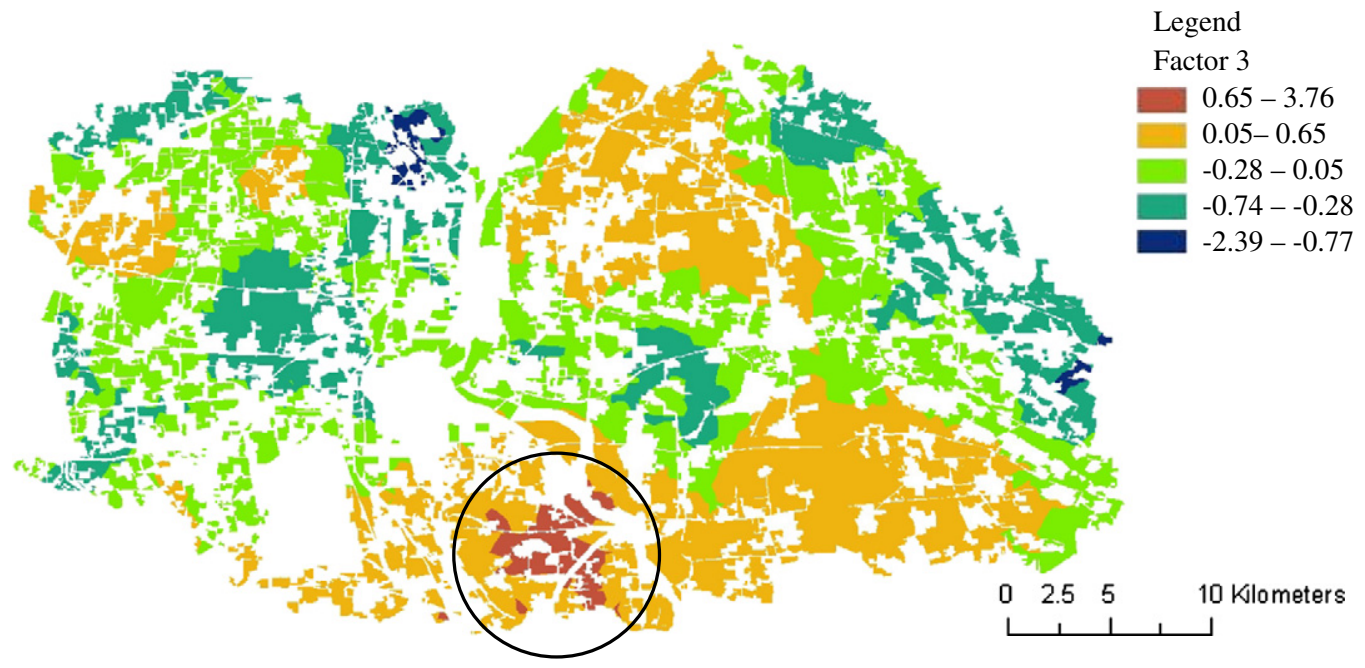

Fig. 8. Filled contour map of factor 3. 
city), between 2 nd and 4 th ring road (outside the city center), and outside 4th ring road, respectively (Chen et al., 2010). In the present study, the average $\mathrm{Hg}$ concentration in the soils was $0.073 \mathrm{mg} \mathrm{kg}^{-1}$. There is a distinct decreasing trend in $\mathrm{Hg}$ concentration from the city center to the suburban areas, which suggests that atmospheric $\mathrm{Hg}$ contamination in the city plays an important role in $\mathrm{Hg}$ accumulation in the agricultural soils in Shunyi.

\section{Conclusions}

The results of this study showed that although a slightly higher than their background values of Beijing topsoil, the concentrations of $\mathrm{As}, \mathrm{Cd}, \mathrm{Cu}, \mathrm{Hg}, \mathrm{Pb}$ and $\mathrm{Zn}$ in the agricultural soils in the Shunyi District were lower than the guideline values of Chinese Environmental Quality Standard for Soils, indicating an insignificant contamination of these metals in this area. Among the metals investigated in this study, soil As and $\mathrm{Pb}$ mainly come from the parent materials. Local contamination from agricultural practices, particularly with the application of fertilizer and manure, is the main source of $\mathrm{Cd}, \mathrm{Cu}$ and $\mathrm{Zn}$ entering the agricultural soils, and atmospheric deposition plays an important role in $\mathrm{Hg}$ accumulation in the soils. This case study demonstrates that a combination of multivariate statistics and geostatistical analysis can be an appropriate tool to characterize heavy metal spatial distribution and to determine their sources. In addition, this study will provide a basis for effectively targeting policies to protect soils from long-term heavy metal accumulation.

\section{Acknowledgments}

This work was funded by the Agro-scientific Research in the Public Interest, the Ministry of Agriculture of the People's Republic of China (Project 201003008) and National Key Technology R\&D Program (Project 2009BADB9B07).

\section{References}

Biasioli M, Barberis R, Ajmone-Marsan F. The influence of a large city on some soil properties and metals content. Sci Total Environ 2006;356:154-64.

Cai Q, Long ML, Zhu M, Zhou QZ, Zhang L, Liu J. Food chain transfer of cadmium and lead to cattle in a lead-zinc smelter in Guizhou, China. Environ Pollut 2009;157:3078-82.

Chary NS, Kamala CT, Raj DSS. Assessing risk of heavy metals from consuming food grown on sewage irrigated soils and food chain transfer. Ecotoxicol Environ Saf 2008;69: 513-24.

Chen M, Ma LQ, Harris WG. Arsenic concentration in Florida surface soils: influence of soil type and properties. Soil Sci Soc Am J 2002;66:632-40.

Chen T, Zheng Y, Chen H, Zheng GD. Background concentration of soil heavy metals in Beijing. Environ Sci (Chinese) 2004;25:117-22.

Chen T, Liu X, Zhu M, Zhao K, Wu J, Xu J, et al. Identification of trace elements sources and associated risk assessment in vegetable soils of the urban-rural transitional area of Hangzhou, China. Environ Pollut 2008;151:67-78.

Chen T, Liu X, Li X, Zhao K, Zhang J, Xu J, et al. Heavy metal sources identification and sampling uncertainty analysis in a field-scale vegetable soil of Hangzhou, China. Environ Pollut 2009;157:1003-10.

Chen X, Xia X, Wu S, Wang F, Guo X. Mercury in urban soils with various types of land use in Beijing, China. Environ Pollut 2010;158:48-54.

Cressie N, Hawkins DM. Robust estimation of the variogram. J Int Assoc Math Geol 1980;7(12):115-25.

Dray S, Said S, Debias F. Spatial ordination of vegetation data using a generalization of Wartenberg's multivariate spatial correlation. J Veg Sci 2008;19:45-56.

Goovaerts P. Geostatistics in soil science: state-of-the-art and perspectives. Geoderma 1999;89:1-45.

Hang X, Wang H, Zhou J, Ma C, Du C, Chen X. Risk assessment of potentially toxic element pollution in soils and rice (Oryza sativa) in a typical area of the Yangtze River Delta. Environ Pollut 2009;157:2542-9.
Ip CCM, Li X, Zhang G, Wai OWH, Li Y. Trace metal distribution in sediments of the Pearl River Estuary and the surrounding coastal area, South China. Environ Pollut 2007; 147:311-23.

Jin YQ, Wang XJ, Lu JL, Zhang CX, Duan QB. Effects of modern and ancient human activities on mercury in the environment in Xi'an area, Shannxi Province, PR China. Environ Pollut 2008;153:342-50.

Khan S, Cao Q, Zheng YM, Huang YZ, Zhu YG. Health risks of heavy metals in contaminated soil and food crops irrigated with waster water in Beijing, China. Environ Pollut 2008;152:686-92.

Lacerda LD, de Souza M, Ribeiro MG. The effects of land use change on mercury distribution in soils of Alta Floresta, Southern Amazon. Environ Pollut 2004:129:247-55.

Lado LR, Hengl T, Reuter H. Heavy metals in European soils: a geostatistical analysis of the FOREGS Geochemical database. Geoderma 2008;148:189-99.

Lark RM. A comparison of some robust estimators of the variogram for use in soil survey Eur J Soil Sci 2000:51:137-57.

Lark RM. Modelling complex soil properties as contaminated regionalized variables. Geoderma 2002;106:171-88.

Lee CS, Li X, Shi W, Cheung SC, Thornton I. Metal contamination in urban, suburban, and country park soils of Hong Kong: a study based on GIS and multivariate statistics. Sci Total Environ 2006;356:45-61.

Liao Q, Evans LJ, Gu X, Fan D, Jin Y, Wang H. A regional geochemical survey of soils in Jiangsu Province, China: preliminary assessment of soil fertility and soil contamination. Geoderma 2007;142:18-28.

Liu X, Wu J, Xu J. Characterizing the risk assessment of heavy metals and sampling uncertainty analysis in paddy field by geostatistics and GIS. Environ Pollut 2006;141: 257-64.

López JM, Borrajo JL, García EDM, Arrans JR, Estévez MCH, Castillo AJS. Multivariate analysis of contamination in the mining district of Linares (Jaén, Spain). Appl Geochem 2008:23:2324-36.

Luo W, Wang T, Lu Y, Giesy JP, Shi Y, Zheng Y, et al. Landscape ecology of the Guanting Reservoir, Beijing, China: multivariate and geostatistical analyses of metals in soils. Environ Pollut 2007;146:567-76

Luo W, Lu Y, Wang G, Shi Y, Wang T, Giesy JP. Distribution and availability of arsenic in soils from the industrialized urban area of Beijing, China. Chemosphere 2008;72: 797-802.

Matheron G. Les variables régionalisées et leur estimation: une application de la théorie des fonctions aléatoires aux sciences de lanature. Paris, France: Masson; 1965. 305pp.

McBride MB, Spiers G. Trace element content of selected fertilizers and dairy manures as determined by ICP-MS. Commun Soil Sci Plan 2001;32:139-56.

Nan ZR, Li JJ, Zhang JM, Cheng GD. Cadmium and zinc interactions and their transfer in soil crop system under actual field conditions. Sci Total Environ 2002;285:187-95.

Navas A, Machín J. Spatial distribution of heavy metals and arsenic in soils of Aragón (northeast Spain): controlling factors and environmental implications. Appl Geochem 2002;17:961-73.

Nicholson FA, Smith SR, Alloway BJ, Carlton-Smith C, Chambers BJ. An inventory of heavy metals inputs to agricultural soils in England and Wales. Sci Total Environ 2003;311:205-19.

R Development Core Team. R: A language and environment for statistical computing. $\mathrm{R}$ Foundation for Statistical Computing, Vienna, Austria. 2011. Available from: http:// www.R-project.org.

Ribiero PJ, Diggle PJ. geoR: a package for geostatistical analysis. R News 2001;1:15-8.

Rodríguez MJA, López AM, Grau CJM. Heavy metal contents in agricultural topsoils in the Ebro basin (Spain). Application of the multivariate geostatistical methods to study spatial variations. Environ Pollut 2006;144:1001-12.

Saby NPA, Arrouays D, Boulonne L, Jolivet C, Pochot A. Geostatisical assessment of Pb in soil around Paris, France. Sci Total Environ 2006;367:212-21.

Saby NPA, Thioulouse J, Jolivet CC, Ratie C, Boulonne L, Bispo A, et al. Multivariate analysis of the spatial patterns of 8 trace elements using the French soil monitoring network data. Sci Total Environ 2009;407:5644-52.

Shi G, Chen Z, Xu S, Zhang J, Wang L, Bi C, et al. Potentially toxic metal contamination of urban soils and roadside dust in Shanghai, China. Environ Pollut 2008;156:251-60.

State Environmental Protection Administration of China. Chinese environmental quality standard for soil GB; 1995.. 15618-1995.

USEPA. Method 3050B: acid digestion of sediments, sludges and soils. United States Environmental Protection Agency; 1996.

$\mathrm{Xu} \mathrm{S,} \mathrm{Tao} \mathrm{S.} \mathrm{Coregionalizaiton} \mathrm{analysis} \mathrm{of} \mathrm{heavy} \mathrm{metals} \mathrm{in} \mathrm{the} \mathrm{surface} \mathrm{soil} \mathrm{of} \mathrm{Inner} \mathrm{Mongolia.}$ Sci Total Environ 2004;320:73-87.

Zheng YM, Chen TB, He JZ. Multivariate geostatistical analysis of heavy metals in topsoils from Beijing, China. J Soils Sediments 2008;8:51-8. 